\title{
Pengaruh Literasi Sains, Pemahaman Qur'an Hadist Dan Kecerdasan Naturalis Terhadap Sikap Peduli Lingkungan
}

\author{
Suhirman \\ Universitas Islam Negeri Mataram, Indonesia \\ suhirman@uinmataram.ac.id
}

\begin{abstract}
Abstrak.Tujuan penelitian ini untuk mengetahui pengaruh literasi sains, pemahaman Quranhadis, dan kecerdasan naturalis terhadap sikap peduli lingkungan siswa madrasah tsanawiyah di Kota Mataram. Populasi dalam penelitian ini adalah seluruh siswa madrasah tsanawiyah di Kota Mataram kelas IX tahun pelajaran 2019/2020 yang berjumlah 1.440 orang. Sampel ditentukan dengan metode cluster random sampling. Penelitian ini melibatkan empat variabel yakni tiga variabel bebas: literasi sains, pemahaman Quran hadis dan kecerdasan naturalis dan satu variabel terikat yakni sikap peduli. Literasi sains, pemahaman Quran hadis dan kecerdasan naturalis dikumpulkan dengan instrument soal tes dan variabel sikap peduli lingkungan dikumpulkan dengan instrumen angket. Data dianalisis dengan menggunakan teknik statistik deskriptif dan statistik inferensial. Uji hipotesis menggunakan analisis regresi linear dan uji $\mathrm{F}$ untuk melihat pengaruh kumulatif variabel bebas $\left(\mathrm{X}_{1}, \mathrm{X}_{2}, \mathrm{X}_{3}\right)$ terhadap variabel terikat $(\mathrm{Y})$. Hasil penelitian menunjukkan Level literasi sains siswa MTs Kota Mataram termasuk katagori rendah. Walaupun demikian, literasi sains berpengaruh positif signifikan terhadap sikap peduli lingkungan siswa MTs di Kota Mataram. Pemahaman Quran Hadis siswa MTs Kota Mataram termasuk katagori sedang. Pemahman Quran Hadis berpengaruh positif tidak signifikan terhadap sikap peduli lingkungan siswa MTs di Kota Mataram. Kecerdasan naturalis siswa MTs Kota Mataram termasuk katagori tinggi. Kecerdasan naturalis berpengaruh negatif signifikan terhadap sikap peduli lingkungan siswa MTs di Kota Mataram. Literasi sains, pemahaman Quran Hadis, dan kecerdasan naturalis berpengaruh positif signifikan bersama-sama terhadap sikap peduli lingkungan siswa MTs di Kota Mataram. Pembelajaran qur'an-hadist dan sains tentang lingkungan hidup seharusnya diimbagi dengan penerapannya dalam kehidupan nyata
\end{abstract}

Kata Kunci: Literasi sains, kecerdasan naturalis, qur'an hadist, sikap peduli lingkungan

\section{PENDAHULUAN}

Masalah degradasi lingkungan seperti yang terjadi di Kota Mataran disebabkan tingkah laku dan ketidakpedualian siswa terhadap lingkungan sekitar, seperti membuang sampah dan limbah. Dengan semakin kompleksnya persoalan lingkungan yang terjadi, diperlukan pengetahuan, sikap, dan prilaku yang arif dan bertanggung jawab bagi manusia untuk mempertahankan kualitas lingkungan sehingga lingkungan tetap mampu menopang kehiudupan umat manusia. Kepedulian terhadap lingkungan menjadi variabel penting dalam mengendalikan kualitas lingkungan. Berbagai permasalahan lingkungan yang terjadi tidak terlepas dari sikap dan perilaku manusia yang bersifat konsumtif dan tidak ramah terhadap lingkungan hidupnya sendiri dan merupakan sebuah penyelewengan terhadap tugas dan kewajiban utamanya yaitu sebagai Khalifah (wakil Tuhan) dalam melestarikan dan memanfaatkan sumberdaya alam sehingga tetap pada daerah keseimbangannya. Karena baik buruknya suatu lingkungan ditentukan oleh pola hidup dan sikap manusia terhadap lingkungan hidupnya.

Kepedulain siswa terhadap lingkungan tidak terlepas dari pengaruh berbagai faktor, yakni faktor eksternal dan internal. Faktor eksternal yang dimaksud di antaranya adalah pembelajaran yang diperoleh siswa pada setiap mata pelajaran yang mereka alami. Pada jenjang pendidikan madrasah tsanawiyah (MTs) sesuai Kurikulum 2013 maupun Kurikulum Tingkat Satuan 
Pendidikan (KTSP), pengetahuan peserta didik yang berkaitan dengan lingkungan hidup secara jelas terdapat pada mata pelajaran sains (IPA) dan mata pelajaran keagamaan yaitu Quran Hadis. Sedangkan faktor internal adalah kecerdasan majemuk (MI), yang dalam penelitian ini memfokuskan pada kecerdasan naturalis atau sering disebut kecerdasan alam..

Memasuki abad 21, terdapat peningkatan secara signifikan tentang masalah lingkungan baik secara regional maupun global (Simsekli, 2015). Lingkungan sebagai penyedia sumber daya merupakan aset yang sangat berharga bagi makhluk hidup terutama manusia. Karena itu, setiap individu selayaknya aktif dalam menjaga dan melindungi lingkungan (Altin, Tecer, Tecer, Altin, \& Fatih, 2014)

Melalui proses pendidikan seseorang mestinya memiliki kepekaan terhadap lingkungan, tanggungjawab dan prilaku yang ramah lingkungan. Materi tentang lingkungan hidup umumnya pada jenjang Madrasah Aliyah terintegrasi dengan mata pelajaran biologi, pada jenjang Madrasah Tsanawiyah terpadu dengan mata pelajaran lainnya dan pada jenjang Madrasah Ibtidaiyah diberikan dalam bentuk tematik.

Dalam beberapa tahun terakhir ini Kota Mataram sering dilanda berbagai masalah lingkungan yang dipicu oleh rendahnya kesadaran dan kepedulian siswa dalam menjaga dan memelihara lingkungan. Ketidakpedulian siswa, rendahnya kesadaran siswa dan prilaku membuang sampah sembarangan ditenggarai sebagai penyebab terjadinya berbagai masalah lingkungan.

Penelitian yang berkaitan dengan kesadaran lingkungan, kepedulian lingkungan dan prilaku menjaga lingkungan lebih banyak dilakukan pada tingkat Perguruan Tinggi, sangat jarang dilakukan pada tingkat sekolah menengah. Siswa harus dapat mengidentifikasi dan memecahkan masalah lingkungan dan memberikan solusi untuk mengatasinya. Solusi ini diharapkan dapat membimbing para siswa untuk menciptakan karya atau produk yang inovatif, baru, menarik, dan bermanfaat (Rosdiana, Subekti, \& Setiawan, 2018).
Terdapat sembilan jenis kecerdasan dalam model ini, yakni linguistik, logismatematis, musikal, spasial, kinestetik-tubuh, antarpribadi, intrapersonal, naturalis, dan eksistensial (Akbari \& Hosseini, 2008). Kecerdasan naturalis merupakan bagian dari kecerdasan majemuk yang dimiliki oleh manusia. Kecerdasan ini meliputi kepekaan terhadap masalah-masalah atau fenomena alam dan kemampuan membedakan makhluk hidup dan makhluk tidak hidup. Kecerdasan naturalistik meruapakan salah satu dari berbagai kecerdasan (multiple intellegences), yang perlu dikembangkan dan ditingkatkan pada masing-masing siswa karena kompetensi tersebut dianggap lemah di Indonesia (Adisendjaja, Abdi, \& Fardhani, 2019). Kecerdasan naturalis berkaitan dengan pemahaman tentang alam, yang mencakup kemampuan untuk mengidentifikasi dan mengklasifikasikan perbedaan dan persamaan antara karakteristik spesies, baik flora dan fauna, seperti tumbuhan, hewan dan lainnya lingkungan hidup, dan mampu berinteraksi secara efektif dengan alam (Zen \& Sihes, 2018).

Pendidikan sains mempunyai peran yang sangat penting dan bermanfaat dalam menunjang kehidupan dan berkontribusi dalam mengembangakan ilmu pengetahuan secara umum. Departemen Pendidikan Indonesia dan Kebudayaan juga telah mempromosikan program literasi sekolah untuk meningkatkan literasi siswa. Generasi yang kompetitif diperlukan dalam ilmu pengetahuan alam dan teknologi yang mengacu pada kemampuan literasi sains (Setiawan et al., 2017). Pikiran ini mendasari gagasan itu literasi ilmiah. Salah satunya tujuan terpenting dari Pendidikan Sains adalah pengembangan literasi sains (Drago \& Mih, 2015). Pentingnya literasi sains di Indonesia berkontribusi dalam pengembangan pendidikan sains. Oleh karena itu, literasi ilmiah telah diakui secara internasional sebagai tolok ukur tingkat kualitas sains pendidikan (Ardianto \& Rubini, 2016).

Studi dari Program for International Student Assessment (PISA) di tahun 2018 menunjukkan bahwa skor literasi sains Indonesia berada di bawah rata-rata (OECD, 
2018), dan hasil studi sebelumnya menunjukkan bahwa hampir setengah dari siswa sekolah menengah atas Indonesia (sebesar 41\%) hanya memiliki pengetahuan terbatas tentang sains (Widowati, Anjarsari, Rahardjo, \& Elfi, 2017). Data ini menunjukkan bahwa para siswa Indonesia masih lemah dalam penguasaan ilmu pengetahuan. Salah satu kelemahan guru sains menengah saat ini adalah lemahnya kemampuan untuk mengembangkan pembelajaran sains terintegrasi (Rubini, Pusitasari, Ardianto, \& Hidayat, 2018). Karena itu, dalam pembelajaran sains, seorang guru perlu mengembangkan literasi siswa agar dapat memperoleh kesuksesan baik dalam pembelajaran maupun dalam kehidupan nyata (Asrizal, Amran, Ananda, Festiyed, \& Sumarmin, 2018).

Literasi ilmiah dapat diklasifikasikan ke dalam empat kategori. Tiga kategori pertama diperkenalkan oleh Shen pada tahun 1975, dalam perkembangannya pada tahun 2008 Trefil menambahkan menjadi empat kategori sebagai berikut: 1) Cultural Scientific Literacy - berarti memahami sains oleh seseorang dengan kecerdasan rata-rata dan pendidikan suatu budaya; 2) Civic Scientific Literacy- mewakili tingkat pemahaman ilmiah yang diperlukan seseorang untuk membuat keputusan berdasarkan informasi sehubungan dengan undang-undang dan kebijakan publik; 3) Praktek Literasi Ilmiah - mengacu pada pengetahuan ilmiah yang harus dipecahkan oleh seseorang secara praktis masalah (expl. Menentukan cara paling efisien untuk memanaskan rumah); 4) Praktek Literasi Ilmiah - mengacu pada pengetahuan ilmiah yang harus dipecahkan oleh seseorang secara praktis masalah (expl. Menentukan cara paling efisien untuk memanaskan rumah).

Guru-guru biologi dan siswa di Indonesia perlu dilengkapi dengan keterampilan literasi biologi dan berpikir kritis untuk mengajar mata pelajaran biologi (Suwono, Pratiwi, Susanto, \& Susilo, 2017). Literasi adalah penting bagi siswa untuk mengetahui, memahami, dan menerapkan ilmu pengetahuan dan teknologi. Literasi sains menggambarkan kemampuan seseorang untuk memahami tentang hukum, teori, konsep, prinsip, dalil dan berbagai fenomena ilmiah lainnya.

Seperti negara-negara lain, kondisi lingkungan alam di Mataram Nusa Tenggara Barat Indonesia semakin hari semkin mengkhawatirkan. Literasi sains, yang dianggap sebagai bagian penting dari pendidikan lingkungan, tampaknya telah diabaikan di sekolah-sekolah wilayah Mataram Nusa Tenggara Barat. Sebagai sebuah konsep yang sedang berkembang, literasi sains merupakan bagian yang tidak terpisahkan dari pendidikan lingkungan (Srbinovski, Erdogan, \& Ismaili, 2010).

Hasil penelitian pendahuluan dengan melakukan wawancara bersama guru-guru mata pelajaran IPA di MTs di Kota Mataram diperoleh gambaran bahwa memang betul pada mata pelajaran IPA siswa diberikan pengetahuan dan pemahaman mengenai lingkungan hidup, pembelajaran dengan diskusi di kelas dan bahkan pengamatan ekosistem yang ada di lingkungan sekolah dan menelaah kasus-kasus lingkungan hidup yang ada di sekitar. Namun menurut guru mata pelajaran IPA, pengetahuan tersebut tampaknya tidak secara keseluruhan memberikan pengaruh pada sikap kepedulian siswa pada lingkungannya. Sebagai contoh buktinya adalah masih terlihat siswa yang membuang sampah di sembarang tempat, menginjak-injak taman di halaman sekolah, dan sebagainya. Demikian juga halnya dengan hasil wawancara bersama guru mata pelajaran quran hadis. Mereka menyampaikan bahwa pada pelajaran quran hadis terdapat bab khusus yang mempelajari tentang hadishadis dan ayat al quran yang berkaitan dengan bagaimana kewajiban atau tunutan kepada manusia untuk melestarikan alam. Misalnya prilaku untuk menjaga bumi dari kerusakan, merawat tanaman, memelihara sumur atau sumber air, tidak mengebiri binantang, dan sebagainya. Menurut guru mata pelajaran quran hadis, sebenarnya materi itu sudah sangat cukup memberikan pengetahuan dan pemahaman kepada siswa untuk melestarikan alam ini. Mengenai praktiknya oleh siswa, semua guru menyadari bahwa belum semua siswa menyadari sepenuhnya akan pentingnya pengetahuan ini menjadi sikap dan prilakunya 
sehari-hari. Kebaruan dalam penelitian ini adalah menguji asumsi masyarakat bahwa selama pemahaman tentang qur'an hadist berbanding lurus dengan pengamalan tentang lingkungan lingkungan.

\section{METODE PENELITIAN}

$\begin{array}{ccr}\text { Penelitian } & \text { ini menggunakan } \\ \text { paradigma expost pacto, data yang }\end{array}$ dikumpulkan dalam penelitian telah ada dan melekat pada subjek penelitian. Variabelvariabel yang diukur merupakan atribut psikologis subjek yang dicari asosiasinya secara sendiri-sendiri maupun secara bersama-sama. Populasi dalam penelitian ini adalah seluruh siswa madrasah Tsanawiyah di Kota Mataram kelas IX Tahun Pelajaran 2019/2020 yang berjumlah 1.440 orang. Sampel ditentukan dengan metode cluster random sampling berdasarkan peringkat akreditasi. Jumlah sampel yang diambil berdasarkan nilai akreditasi dengan asumsi akreditasi A sebanyak 2 madrasah, B sebanyak 3 madrasah dan C sebanyak 2 madrasah untuk memperoleh $35 \%$ sampel dari populasi.

Analisis statistik deskriptif dilakukan untuk mendeskripsikan setiap data yang diperoleh pada masing-masing variabel. Pendeskripsian data diupayakan secara ringkas dan jelas dengan maksud untuk mengetahui karakteristik sampel. Informasi yang diperoleh dari hasil deskripsi ini adalah nilai maksimum, nilai minimum, mean, median, standar deviasi, dan varians. Selain itu, data juga disajikan dalam bentuk grafik histogram data kelompok dan distribusi frekuensi data kelompok. Hal ini dimaksudkan untuk mendukung kajian pembahasan pada analisis statistik inferensial. Nilai variabel literasi sains, pemahaman qur'an hadis, dan kecerdasan naturalis siswa dikatagorisasi berdasarkan penilaian acuan patokan (PAP). Analisis statistik inferensial digunakan pada analisis yang berkaitan dengan uji persyaratan analisis dan uji hipotesis. Uji persyaratan yang dilakukan, yaitu; uji normalitas sebaran data, uji linearitas, dan uji kolinearitas variabel. Uji hipotesis menggunakan analisis regresi linear dan uji $\mathrm{F}$ untuk melihat pengaruh kumulatif variabel bebas $\left(\mathrm{X}_{1}, \mathrm{X}_{2}, \mathrm{X}_{3}\right)$ terhadap variabel terikat (Y).

\section{HASIL DAN PEMBAHASAN}

Setelah semua uji statistik prasyarat dilakukan dan hasil uji terpenuhi, langkah selanjutnya adalah menguji hipoteis penelitian. Uji hipotesis ini sebagai uji inti dalam rangka menjawab rumusan masalah penelitian. Sesuai dengan desain penelitian, maka uji hipotesis yang digunakan adalah dengan statistik regresi menggunakan SPSS 16.0.

Tabel 1. Rekapitulasi Hasil Pengujian Regresi antar Variabel Penelitian

\begin{tabular}{|c|c|c|c|c|c|}
\hline & \multicolumn{2}{|c|}{ Unstandardized Coefficients } & $\begin{array}{c}\text { Standardized } \\
\text { Coefficients }\end{array}$ & \multirow{2}{*}{ t } & Sig. \\
\cline { 2 - 4 } & B & Std. Error & Beta & & \\
\hline (Constant) & 3,082 & 0,170 & & 18,097 & 0,000 \\
\hline Lit_X1 & 0,002 & 0,001 & 0,199 & 2,184 & 0,030 \\
\hline QH_X2 & 0,001 & 0,001 & 0,120 & 1,340 & 0,182 \\
\hline Nat_X3 & $-0,006$ & 0,003 & $-0,159$ & $-2,097$ & 0,037 \\
\hline a. Dependent Variable: Sikap_Y & & & & \\
\hline
\end{tabular}

$\beta 1=0,002 \quad \beta 2=0,001 \quad \beta 3=-0,006$

Berdasarkan Tabel 1 di atas dapat diketaui besarnya koefisien regresi antara variabel bebas (X1, X2, dan X3) dengan variabel terikat (Y). Koefiesien tersebut menggambarkan pengaruh variabel bebas (X) terhadap variabel terikat $(\mathrm{Y})$. Literasi sains $\left(\mathrm{X}_{1}\right)$ berpengaruh positif terhadap sikap peduli lingkungan siswa $(\mathrm{Y}), \beta 1=0,002>0$, dengan nilai probabilitas $(p)=0,030(p<0,05)$, artinya $\mathrm{H}_{0}$ ditolak. Dengan demikian, literasi sains berpengaruh positif signifikan terhadap sikap peduli lingkungan siswa MTs di Kota Mataram. Pemahaman Quran Hadis $\left(\mathrm{X}_{2}\right)$ berpengaruh positif terhadap sikap peduli lingkungan siswa $(\mathrm{Y}), \beta_{2}=0,001>0$, dengan nilai probabilitas $(p)=0,183(p>0,05)$, artinya H0 diterima. Dengan demikian, pemahman Quran Hadis berpengaruh positif tidak signifikan terhadap sikap peduli lingkungan siswa MTs di Kota Mataram. Kecerdasan naturalis $\left(\mathrm{X}_{3}\right)$ berpengaruh positif terhadap sikap peduli lingkungan siswa $(\mathrm{Y})$, $\beta 3=-0,006<0$, dengan nilai probabilitas $(p)$ $=0,037(p<0,05)$, artinya $\mathrm{H} 0$ ditolak. Dengan demikian, kecerdasan naturalis berpengaruh negatif signifikan terhadap sikap peduli lingkungan siswa MTs di Kota Mataram. Literasi sains $\left(\mathrm{X}_{1}\right)$, pemahaman 
Quran Hadis $\left(\mathrm{X}_{2}\right)$, dan Kecerdasan naturalis $\left(\mathrm{X}_{3}\right)$ berpengaruh positif bersama-sama terhadap sikap peduli lingkungan siswa (Y)

Tabel 8. Rekapitulasi hasil ANOVA

\begin{tabular}{|l|c|c|c|c|c|}
\hline & Sum of Syutures & df & $\begin{array}{c}\text { Mecin } \\
\text { Squure }\end{array}$ & Nilai F & Nilaip \\
\hline Regression & 0,774 & 3 & 0,258 & 5,031 & $0,002^{2}$ \\
\hline Residual & 11,534 & 225 & 0,051 & & \\
\hline Total & 12,308 & 228 & & & \\
\hline
\end{tabular}

a. Predictors: (Constant), X3, X2, X1)

b. Dependent Variable: Y

Nilai $\mathrm{F}=5,031$, dengan nilai probabilitas $(p)=0,02(p<0,05)$, artinya $\mathrm{H} 0$ ditolak. Dengan demikian, literasi sains, pemahaman Quran Hadis, dan kecerdasan naturalis berpengaruh positif signifikan bersama-sama terhadap sikap peduli lingkungan siswa MTs di Kota Mataram. Pembentukan sikap peduli lingkungan siswa akan berkembang dengan baik ketika masalah lingkungan hadir. Siswa akan tergerak untuk memiliki sikap positif terhadap lingkungan Hidup (Amin \& Bashith, 2018). Sikap peduli lingkungan dipengaruhi oleh pengalaman diri sendiri, keteladanan orang lain, budaya lokal dan tingkat pendidikan seseorang. Sikap ini akan membentuk konsep diri yang positif bagi siswa dalam merespons dan berperilaku dengan prinsip-prinsip ekologis (Amin \& Bashith, 2018).

Ketidaksesuaian penanaman konsep sains pada siswa tercermin dari karakter yang cenderung menganggu lingkungan (Khusniati, 2014). Hal ini terbukti dari berbagai permasalahan lingkungan seperti kekeringan berkepanjangan, banjir, erosi, kebakaran hutan, pencemaran dan berbagai masalah lingkungan yang belum dapat diatasi hingga saat ini. Untuk mengatasi dampak dari kerusakan lingkungan sudah banyak dilakukan kajian. Salah satu yang menarik adalah menanamkan kepedulian kepada siswa sejak dini baik secara formal, non formal maupun informal. Kearifan lokal juga perlu diberdayakan melalui pesan-pesan yang mengarah kepada keharmonisan lingkungan alam. Sehingga dapat dijadikan sebagai penguatan dan memberikan motivasi dalam memelihara lingkungan.

Hasil penelitian menunjukkan bahwa, level literasi sains siswa MTs yang menjadi sampel penelitian adalah termasuk katagori rendah. Walaupun demikian, literasi sains siswa berpengaruh positif signifikan terhadap sikap peduli lingkungan siswa. Siswa-siswa MTs di Kota Mataram tampaknya baru mampu mengingat pengetahuan ilmiah berdasarkan fakta sederhana. Evaluasi literasi sains yang dilakukan oleh PISA, memberikan perhatian terhadap aspek kognitif dan afektif (OECD, 2018). Tujuannya untuk memperbaiki kualitas pendidikan yang terfokus pada literasi sains, membaca, dan matematika. PISA menetapkan tiga aspek dari komponen proses sains yakni mengidentifikasi pertanyaan ilmiah, menjelaskan fenomena secara ilmiah, dan menggunakan bukti ilmiah. Itu berarti, komponen proses sains berkaitan dengan pengembangan literasi sains dan sikap ilmiah. Capaian penilaian sains merupakan bagian yang terpenting dalam penilaian PISA dan TIMSS, sehingga diupayakan untuk memperbaiki prestasi sains, baik secara nasional maupun internasional.

Literasi sains sangat penting dikembangkan, karena (1) dapat memahami dan mempelajari sains dengan baik. (2) Dalam kehidupan sehari-hari, setiap manusia membutuhkan informasi dan berpikir ilmiah untuk pengambilan keputusan. (3) Setiap orang perlu melibatkan kemampuannya dalam wacana publik dan debat mengenai isu-isu penting yang melibatkan sains dan teknologi. (4) Literasi sains penting dalam dunia kerja, karena membutuhkan keterampilanketerampilan yang tinggi dengan bernalar, berpikir secara kreatif, membuat keputusan dan memecahkan masalah (Ardianto \& Rubini, 2016). Dengan demikian, sains seharusnya diajarkan dengan proses menyenangkan dan diminati oleh mahasiswa. Namun, tidak dapat dipungkiri bahwa pelajaran sains masih berorientasi pada sains sebagai pengetahuan dan sains sebagai produk saja dengan menghafalkan konsep-konsep sains dan rumus-rumus sains.

Hasil penelitian menunjukkan bahwa, pemahaman Quran Hadis siswa MTs yang menjadi sampel penelitian adalah termasuk katagori sedang. Pemahaman Quran Hadis berpengaruh positif tidak signifikan terhadap 
sikap peduli lingkungan siswa. Dalam Islam, peduli lingkungan ataupun pelestarian terhadap lingkungan berawal dari penyerahan amanah kepada manusia. Kemampuan atas potensi manusia menyebabkan manusia lebih mampu memikul amanah Allah. Sehingga, diciptakan manusia di bumi ini adalah untuk menjadi abdullah dan khalifatullah (Rodin, 2017).

Manusia diharapkan menjaga dan saling kasih sayang dengan seluruh potensinya yang baik terhadap makhluk Allah. Dengan demikian, manusia dapat memimpin dan mengelola seluruh alam tanpa merugikan makhluk lain. Oleh karena itu, manusia diminta agar senantiasa berperilaku baik terhadap semua makhluk Allah seperti sesama manusia, hewan, maupun alam dan dilarang untuk merusaknya. Dalam al-Qure an surat al-Qashash ayat 77 yang artinya:

"Dan carilah pada apa yang telah dianugerahkan Allah kepadamu (kebahagiaan) negeri akhirat, dan janganlah kamu melupakan bahagianmu dari (kenikmatan) duniawi dan berbuat baiklah (kepada orang lain) sebagaimana Allah telah berbuat baik, kepadamu, dan janganlah kamu berbuat kerusakan di (muka) bumi. Sesungguhnya Allah tidak menyukai orangorang yang berbuat kerusakan".

Dalam tafsir Ibnu Katsir, ayat diatas menerangkan bahwa manusia diperintahkan untuk menggunakan apa yang telah dianugerhakan Allah bagi manusia berupa harta yang melimpah dan kenikmatan yang panjang dalam berbuat taat kepada Allah serta betaqarrub kepada-Nya dengan berbagai amal-amal yang dapat menghasilkan pahala di dunia dan akhirat. Manusia diperbolehkan menikmati kenikmatan di dunia berupa makan, minum, pakaian, tempat tinggal dan pernikahan. Sehingga ciptaan Allah mempunyai hak masing-masing. Maka dalam memberikan hak setiap sesuatu sesuai haknya. Allah memerintahkan untuk selalu berbuat baik kepada makhlukNya sebagaimana

Salah satu kebaikan tersebut diantaranya adalah dengan memberikan air untuk tanaman maupun hewan, karena air merupakan sumber penghidupan makhluk hidup, maka pencemaran air berakibat pada kerusakan bagi kehidupan. Memberikan air kepada sesama makhluk hidup merupakan shadaqah bagi yang memberikan. Dalam buku shahih sunan Abu Daud hadis jilid 3, nomer 1679 tentang keutamaan air yakni Air adalah shadaqah yang disukai Nabi. Shadaqah air tidak hanya memberi minum kepada sesama manusia saja, tetapi juga sesama makhluk Allah, seperti tumbuhan dan hewan yang memerlukan air untuk kehidupan mereka. Memberikan air kepada hewan yang sedang haus juga menyirami tumbuhan merupakan shadaqah manusia yang bernilai ibadah. Dengan bershadaqah, pahala akan semakin meningkat.

Hasil analisis menunjukkan kecerdasan naturalis siswa MTs sampel penelitian termasuk katagori tinggi. Kecerdasan naturalis berpengaruh negatif signifikan terhadap sikap peduli lingkungan siswa. Hal ini berarti bahwa, semakin tinggi kecerdasan naturalis siswa, semakin berkurang sikap kepeduliannya terhadap lingkungan. Temuan ini berbeda dengan temuan yang sudah ada. Bahwa kecerdasan naturalis berkontribusi dan berpengaruh terhadap karakter peserta didik sebesar 2,2\%, termasuk karakter peduli lingkungan (Yusuf, Suhirman, I Wayan Suastra, 2019).

Faktor bias penelitian diprediksi mempengaruhi temuan di atas. Pengukuran sikap peduli lingkungan siswa dalam penelitian ini salah satunya mengunakan instrumen lembar penilaian diri. Pada instrument tersebut siswa diminta untuk menilai sikap mereka sendiri. Mereka diminta memberikan skor yang sesuai dengan kondisi diri dengan cara membubuhkan tanda centang (V) pada kolom angka; 4, jika selalu melakukan, 3, jika sering melakukan, 2 jika kadang-kadang melakukan, dan 1 jika tidak pernah melakukan. Kecenderungan siswa dan kita secara umum ketika memberikan penilaian terhadap diri sendiri biasanya memberikan angka-angka yang di tengah atau angka yang lebih tinggi, yaitu 3 atau 4. Pola seperti ini yang menimbulkan bias hasil perhitungan skor sikap peduli lingkungan siswa.

Pengaruh tersebut berasal dari kemampuan siswa yang dimiliki sebelumnya 
berasal dari faktor genetik dan interaksi dengan lingkungan dalam memahami objek makhluk hidup dan gejala-gejala yang bekaitan dengan makhluk hidup dan alam sekitar. Kecerdasan naturalis yang dimiliki siswa menjadi modal awal untuk belajar dari pengalaman dan beradaptasi dengan masalah yang dihadapinya. Menurut Samsudin, kecerdasan naturalis siswa membantu mereka berinteraksi dengan bahan yang berkaitan dengan makhluk hidup sehingga mempengaruhi hasil belajarnya.

Kecerdasan juga berarti kemampuan memperoleh dan mengenali pengetahuan, menggunakan pengetahuan untuk memahami konsep-konsep konkret dan abstrak, mengasosiasikan antara ide dan objek, serta menerapkan pengetahuan yang dimiliki secara efektif. Pada saat yang bersamaan, kecerdasan naturalis sebagai salah bentuk kecerdasan, membantu siswa dalam mempelajari, mengetahui, dan memahami hal-hal yang berkaitan dengan alam sekitar. Siswa dengan kecerdasan naturalis, tidak hanya mampu memperoleh, memahami, dan menerapkan konsep-konsep yang berkaitan dengan alam, tapi juga sekaligus memiliki minat yang tinggi terhadap lingkungan sekitarnya (Suhirman, 2017). Siswa dengan kecerdasan naturalis akan dengan lebih mudah mengikuti materi pelajaran ketika materi tersebut berkaitan dengan alam sekitar dan lingkungan hidup (Suhirman \& Yusuf, 2019).

\section{KESIMPULAN}

Berdasarkan hasil analisis data penelitian dan pembahasan dapat disimpulkan sebagai berikut: level literasi sains siswa MTs Kota Mataram termasuk katagori rendah. Walaupun demikian, literasi sains berpengaruh positif signifikan terhadap sikap peduli lingkungan siswa MTs di Kota Mataram. Pemahaman Quran Hadis siswa MTs Kota Mataram termasuk katagori sedang. Pemahman Quran Hadis berpengaruh positif tidak signifikan terhadap sikap peduli lingkungan siswa MTs di Kota Mataram. Kecerdasan naturalis siswa MTs Kota Mataram termasuk katagori tinggi. Kecerdasan naturalis berpengaruh negatif signifikan terhadap sikap peduli lingkungan siswa MTs di Kota Mataram. Literasi sains, pemahaman Quran Hadis, dan kecerdasan naturalis berpengaruh positif signifikan bersama-sama terhadap sikap peduli lingkungan siswa MTs di Kota Mataram.

Hasil penelitian ini berkontribusi strategis terhadap penyelenggaraan pembelajara sains dan pembelajaran mata pelajaran Quran Hadis di madrasah Tsanawiyah. Pembahasan mengenai ayat-ayat dan hadis tentan lingkungan hidup pada mata pelajaran Quran Hadis harus mendapatkan perhatian khusus dalam rangka mengembangkan sikap peduli siswa terhadap lingkungan. Di samping itu, segala daya dan upaya harus dilakukan dalam rangka meningkatkan literasi sains siswa. Literasi sains siswa akan berpengaruh terhadap sikap peduli siswa terhadap lingkungan, dan bahkan berpengaruh terhadap aspek-aspek kompetensi siswa yang lain.

\section{REFERENSI}

Amin, S., \& Bashith, A. (2018). Proceeding International Conference of Islamic Education: " Information Technology and Media: Challenges and Opportunities " Faculty of Tarbiyah and Teaching Training Universitas Islam Negeri Maulana Malik Ibrahim Malang Urgency of Formal Education for, 1317.

Adisendjaja, Y. H., Abdi, M. M. K., \& Fardhani, I. (2019). The influence of field trip on junior high School students' naturalistic intelligence and problemsolving skills in ecosystem subject. Jurnal Pendidikan IPA Indonesia, 8(3), 339-346.

Akbari, R., \& Hosseini, K. (2008). Multiple intelligences and language learning strategies: Investigating possible relations, 36, 141-155.

Altin, A., Tecer, S., Tecer, L., Altin, S., \& Fatih, B. (2014). Environmental awareness level of secondary school students: A case study in Bal 1 kesir ( Türkiye ). Procedia - Social and Behavioral Sciences, 141, 1208-1214.

Ardianto, D., \& Rubini, B. (2016). Comparison of students ' scientific literacy in integrated science learning 
through model of guided discovery and problem based learning. Jurnal Pendidikan IPA Indonesia, 5(1), 31-37.

Asrizal, Amran, A., Ananda, A., Festiyed, F., \& Sumarmin, R. (2018). The development of integrated science instructional materials to improve students ' digital literacy in scientific approach. Jurnal Pendidikan IPA Indonesia, 7(4), 442-450.

Bulut, N., Serin, O., Yavuz, M. A., \& Muhammedzade, B. (2009). The relationship between the primary teachers 'teaching strategies and their strengths in multiple intelligences ( Their multiple intelligence types ) ( Sampling: Izmir and Lefkosa ), 1, 708-712.

Drago, V., \& Mih, V. (2015). Scientific Literacy in School. Procedia: Social and Behavioral Sciences, 209(July), 167172.

Khusniati, M. (2014). Model Pembelajaran Sains Berbasis Budaya. Indonesian Journal of Conservation, 3(1), 67-74.

OECD. (2018). What 15-year-old students in Indonesia know and can do. Programme for International Student Assessment (PISA) Result from PISA 2018, 1-10.

Rodin, D. (2017). Alquran dan konservasi lingkungan: telaah ayat-ayat ekologis. Al-Tahrir: Jurnal Pemikiran Islam, 17(2), 391.

Rosdiana, L., Subekti, H., \& Setiawan, B. (2018). Jurnal Pendidikan IPA Indonesia Strengthening students ' characters and ecopreneurship through science, environment, technology, and society course, 7(2), 162-171.

Rubini, B., Pusitasari, I. D., Ardianto, D., \& Hidayat, A. (2018). Science teachers, understanding on science literacy and integrated science learning: lesson from teachers training. Jurnal Pendidikan IPA Indonesia, 7(3), 259-265.

Setiawan, B., Innatesari, D. K., Sabtiawan, W. B., \& Sudarmin. (2017). The development of local wisdom-based natural science module to improve science literation of students. Jurnal Pendidikan IPA Indonesia, 6(1), 49-54.

Simsekli, Y. (2015). An Implementation To
Raise Environmental Awareness Of Elementary Education Students. Procedia - Social and Behavioral Sciences, 191, 222-226.

Srbinovski, M., Erdogan, M., \& Ismaili, M. (2010). Environmental literacy in the science education curriculum in Macedonia and Turkey. Procedia Social and Behavioral Sciences, 2(2), 45284532.

Suhirman. (2017). Pengaruh pembelajaran berbasis masalah dan kecerdasan naturalis terhadap kemampuan siswa dalam memecahkan masalah lingkungan hidup (Studi eksperimen di SMPN 1 Mataram NTB). Jurnal Ilmiah Pendidikan Lingkungan Dan Pembangunan, 13(1), 1.

Suhirman, S., \& Yusuf, Y. (2019). The effect of problem-based learning and naturalist intelligence on students' understanding of environmental conservation. JPBI (Jurnal Pendidikan Biologi Indonesia), $5(3)$.

Suwono, H., Pratiwi, H. ., Susanto, H., \& Susilo, H. (2017). Enhancement of student' biological literacy and critical thinking of biology through sociobiological. Jurnal Pendidikan IPA Indonesia, 6(2).

Widowati, A., Anjarsari, P., Rahardjo, S. B., \& Elfi, V. H. (2017). The Development of Scientific Literacy through Nature of Science ( NoS ) within Inquiry Based Learning Approach The Development of Scientific Literacy through Nature of Science ( NoS ) within Inquiry Based Learning Approach. Journal of Physics: Conference Series, 909, 1-7.

Yusuf, Suhirman, I Wayan Suastra, M. K. T. (2019). The effects of problem-based learning with character emphasis and naturalist intelligence on students' problem-solving skills and care. International Journal of Innovation, Creativity and Change, 5(3), 685-707.

Zen, Z., \& Sihes, A. J. bin. (2018). Improvement of natural intelligence for kindergarten through discovery learning (Case study by using artificial environment), 169(Icece 2017), 255- 
Jurnal Ilmiah Mandala Education

http://ejournal.mandalanursa.org/index.php/JIME/index terakreditasi Peringkat 4 (No. SK: 36/E/KPT/2019)
Vol. 6. No. 1. April 2020

p-ISSN: 2442-9511 e-ISSN: 2656-5862

259. 